\title{
Differential gene expression in dairy cows under negative energy balance and ketosis: A systematic review and meta-analysis
}

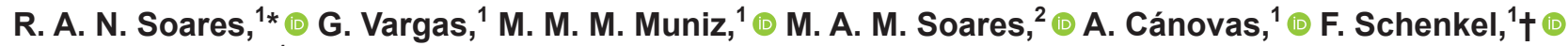 \\ and E. J. Squires ${ }^{1} \dagger$ (i) \\ ${ }^{1}$ Department of Animal Biosciences, Center for Genetic Improvement of Livestock, University of Guelph, Guelph, Canada, N1G 2W1 \\ ${ }^{2}$ Federal Rural University of Rio de Janeiro, Seropédica-RJ, Brazil, 23897-000
}

\begin{abstract}
Development of ketosis in high-producing dairy cows contributes to several animal health issues and highlights the need for a better understanding of the genetic basis of metabolic diseases. To evaluate the pattern of differential gene expression in the liver of cows under negative energy balance (NEB), and under subclinical and clinical ketosis, a meta-analysis of gene expression and genome-wide association studies results was performed. An initial systematic review identified 118 articles based on the key words "cow," "liver," "negative energy balance," "ketosis," "expression," "qPCR," "microarray," "proteomic," "RNA-Seq," and "GWAS." After further screening for only peer-reviewed and pertinent articles for gene expression during NEB and clinical and subclinical ketosis (considering plasma levels of $\beta$-hydroxybutyrate), 20 articles were included in the analysis. From the systematic review, 430 significant SNPs identified by genome-wide association studies (GWAS) were assigned to genes reported in gene expression studies by considering chromosome and base pair positions in the ARS-UCD 1.2 bovine assembly. Venn diagrams were created to integrate the data obtained in the systematic review, and Gene Ontology enrichment analysis was carried out using official gene names. A QTL enrichment analysis was also performed to identify potential positional candidate loci. Twenty-four significant SNPs were located within the coordinates of differentially expressed genes located on chromosomes $2,3,6,9,11,14,27$, and 29. Three significant metabolic pathways were associated with NEB and subclinical and clinical ketosis. In addition, 2 important genes, PPARA (peroxisome proliferator activated receptor alpha) and $A C A C A$ (acetyl-coenzyme
\end{abstract}

Received May 11, 2020.

Accepted September 6, 2020.

*Corresponding author: riani@uoguelph.ca

$\dagger$ These authors contributed equally to this work.
A carboxylase $\alpha$ ), were identified, which were differentially expressed in the 3 metabolic conditions. The $P P A R A$ gene is involved in the regulation of lipid metabolism and fatty liver disease and the $A C A C A$ gene encodes an enzyme that catalyzes the carboxylation of acetyl-coenzyme $\mathrm{A}$ to malonyl-coenzyme $\mathrm{A}$, which is a rate-limiting step in fatty acid synthesis. Gene network analysis revealed co-expression interactions among 34 genes associated with functions involving fatty acid transport and fatty acid metabolism. For the annotated QTL, 9 QTL were identified for ketosis. The genes FN1 (fibronectin 1) and PTK2 (protein tyrosine kinase 2), which are mainly involved in cell adhesion and formation of extracellular matrix constituents, were enriched for QTL previously associated with the trait "ketosis" on chromosome 2 and for the trait "milk iron content" on chromosome 14, respectively. This integration of gene expression and GWAS data provides an additional understanding of the genetic background of NEB and subclinical and clinical ketosis in dairy cattle. Thus, it is a useful approach to identify biological mechanisms underlying these metabolic conditions in dairy cattle.

Key words: $\beta$-hydroxybutyrate, functional enrichment analysis, gene expression, GWAS, meta-analysis

\section{INTRODUCTION}

During the initial lactation period, dairy cows experience a period of negative energy balance (NEB) caused by insufficient dietary intake to meet the animal's requirements for maintenance and milk production (Leek and Reece, 2014; Seymour et al., 2019). As a result, cows must mobilize adipose reserves to meet these requirements and maintain a high level of milk production; consequently, they lose about $60 \%$ or more of their body fat in the first weeks after calving (Kadokawa and Martin, 2006; Renate and Cernescu, 2009). Dairy cows that are unable to adapt to NEB have an increased risk of developing metabolic disorders, such as subclinical or clinical ketosis and fatty liver. Ketosis is a major metabolic disorder of dairy cows in early lactation and 
is defined as the presence of increased concentrations of ketone bodies such as acetoacetate, BHB, and acetone, and a concurrent low level of glucose in the blood (Andersson, 1988).

These metabolic disorders are a common problem in dairy farms and may lead to significant economic losses. At least $50 \%$ of dairy cows undergo a temporary period of subclinical ketosis in the first month of lactation (Esposito et al., 2014; Biswal et al., 2016). McArt et al. (2012) reported an average incidence of $43 \%$ of ketosis in North America during the first 2 wk of lactation. On average, each case of subclinical and clinical ketosis can result in losses of $\$ 203$ and $\$ 289$, respectively, because of decreased milk production, extended interval from calving to conception, and increased risk of displaced abomasum (Geishauser et al., 1998; Geishauser et al., 2001; McArt et al., 2015; Gohary et al., 2016).

Despite NEB being essentially universal among highyielding dairy cows during the peripartum period, some animals are naturally capable of recovering and do not develop subclinical or clinical ketosis. The NEB condition causes breakdown of triglycerides within the adipose tissue, resulting in the release of nonesterified fatty acids (NEFA). The liver plays a crucial role in removing a large portion of NEFA by metabolism to ketone bodies or re-esterification to produce triglycerides. In addition, skeletal muscle has an essential role in adaptation to NEB by using fat-derived fuels, such as NEFA and ketone bodies (Emery et al., 1992; Reynolds et al., 2003).

Previous genetic studies reported heritability estimates for clinical ketosis ranging from 0.02 to 0.16 and for subclinical ketosis ranging from 0.04 to 0.17 (Lee et al., 2016; Pryce et al., 2016). The low heritability estimates for this trait may be due to the subjective nature of its diagnosis, since BHB, an indicator trait for ketosis, has a relatively higher heritability of 0.14 to 0.28 (van der Drift et al., 2012). To better understand this metabolic problem, several studies have investigated the biological processes, metabolic pathways, candidate genes, and gene networks that influence NEB and subclinical and clinical ketosis in dairy cows by performing gene expression and GWAS (McCabe et al., 2012; Ha et al., 2015; Tetens et al., 2015; Huang et al., 2019; Nayeri et al., 2019). The relationship among patterns of gene expression that occur as the clinical condition progresses from NEB to ketosis could be better understood by connecting information of the main metabolic pathways associated with this process. Thus, the objective of this study was to carry out a systematic review and meta-analysis from previously published studies to identify consistent biological information across gene expression and GWAS results for NEB and subclinical and clinical ketosis in dairy cattle.

\section{MATERIALS AND METHODS}

\section{Search of the Published Literature}

A systematic review of NEB and subclinical and clinical ketosis in dairy cattle was carried out as described by Fonseca et al. (2018) to identify significant SNPs located within genomic regions overlapping with candidate genes that are differentially expressed under these metabolic conditions. Different transcriptomic techniques for gene expression studies were considered, including microarray, quantitative PCR (qPCR), and RNA-Sequencing (RNA-Seq). In addition, differentially expressed gene products detected by proteomic studies were also considered. The key words "cow," "liver," "negative energy balance," "ketosis," "expression," "qPCR," "microarray," "proteomic," "RNA-Seq," and "GWAS" were entered into 3 different databases: Google scholar (https://scholar.google.com.br/), PubMed (https://www.ncbi.nlm.nih.gov/pubmed/), and JANE (http://jane.biosemantics.org/) to perform this search.

The databases contained references in all languages, but our search was limited to complete references written in English. The first screening was performed on titles and abstracts of all papers to ensure their relevance, and if the information was not available or was judged irrelevant to the research question of gene expression in NEB and subclinical and clinical ketosis, the reference was excluded. Only peer-reviewed and pertinent articles were obtained in full and assessed. Some additional criteria were applied to this step, such as only references on dairy cows were selected. Also, gene expression data from 3 transcriptomic techniques (microarray, qPCR, or RNA-Seq) and proteomic studies were kept. The metabolic condition of the cow had to be clearly stated, and only information from cows that did not receive any treatment to reverse NEB was kept. For articles with relevant information, but which did not clearly report the animal's clinical condition, plasma BHB concentration was adopted as a criterion. Concentrations of BHB $\leq 0.6 \mathrm{~m} M$ were classified as control animals, concentrations $\geq 1.2 \mathrm{~m} M$ were classified as subclinical ketosis, and values $\geq 3.0 \mathrm{~m} M$ as clinical ketosis (Zhu et al., 2019).

\section{Metabolic Pathway Analysis}

The pathways associated with NEB and subclinical and clinical ketosis were investigated through a permutation analysis approach proposed by Cabrera et al. (2012). For this, 430 significant SNPs obtained from 4 GWAS (Supplemental Table S1; https://doi .org/10.3168/jds.2020-18883) were aligned against the 
locations of genes identified in gene expression studies using the ARS-UCD 1.2 bovine reference genome assembly. Thus, only SNPs located within differentially expressed genes were retained. The SNPs were then ordered according to chromosomal location. According to Cabrera et al. (2012), this approach can establish the significance level of pathways, considering the linkage disequilibrium and the clustering of functionally related genes over the genome.

For each permutation, gene $P$-values were calculated using Fisher's combination test, followed by the hypergeometric test to identify significant pathways (Cabrera et al., 2012). This process was run over 10,000 times to obtain the test statistic distribution under the null hypothesis that the genes in a pathway are not more associated with the phenotype than are the nonpathway genes. A comparison-wise threshold of $0.0002(0.05 / 225)$ was used based on Bonferroni correction and considering a database of 225 pathways obtained from the Kyoto Encyclopedia of Genes and Genomes database (KEGG.db, Kanehisa et al., 2012) from Bioconductor (Carlson et al., 2016). The analyses were performed using the genomicper package (Cabrera et al., 2016) in R (R Core Team, 2019).

\section{Venn Diagrams and Enrichment Analysis}

Venn diagrams were created using the official gene names obtained from the systematic review to integrate the available information. The Venn diagram tool available at http://bioinformatics.psb.ugent.be/ webtools/Venn/ was used to calculate the intersections between gene lists detected from the articles analyzed here (Cánovas et al., 2014). Among them, information from different transcriptomic and proteomic studies to identify genes that were differentially expressed in the liver of cows under NEB and subclinical and clinical ketosis conditions was included.

The GeneMANIA software (www.genemania.org) implemented as a plug-in on the Cytoscape platform (Warde-Farley et al., 2010) was used to investigate possible interactions among the genes detected in the permutation analysis carried out in the pathway analysis. This analysis searches for related genes on publicly available biological data sets and classifies the links in the network based on their relationship, such as coexpression, physical interaction, genetic interaction, shared protein domains, co-localization, and pathway. Furthermore, this analysis uses a pie graphic to show functions associated with genes in the network and their false discovery rate and coverage (as number of genes annotated with that function in the network versus number of genes annotated with that function in the genome). This gene network analysis could provide a better understanding of the genetic architecture of complex polygenic traits.

\section{QTL Enrichment Analysis}

From the above analyses, a list of SNPs associated with differentially expressed genes was used for gene and QTL annotation using R (Version 1.1.463; R Core Team, 2019) and the GALLO R package for genomic functional annotation of positional candidate loci in livestock (https://github.com/pablobio/GALLO). The .gtf format file corresponding to the bovine gene annotation and the .gff format file with the QTL information from Animal QTL Database (Hu et al., 2013) were used for gene and QTL annotation using the ARS-UCD1.2 bovine genome assembly coordinates, respectively. In addition, to identify the potential effects of polymorphisms in cattle traits, QTL enrichment analysis was performed. Single nucleotide polymorphisms associated with any of the 6 trait classes (e.g., reproduction, milk, production, exterior, meat and carcass, and health) were considered for QTL enrichment analysis.

\section{RESULTS}

A total of 118 articles were initially identified from the systematic review after applying the key words into the databases. After screening titles and abstracts and removing duplicate articles, 76 unique articles were available. Following this, 33 articles were excluded as they did not meet the criterion of gene expression for NEB and subclinical and clinical ketosis. After this screening, 43 articles were kept for the next step. Further review was performed, and only articles including expression data from microarray, qPCR, RNA-Seq studies, and proteomic studies with clearly stated metabolic conditions were kept, leaving 20 articles considered appropriate for analysis (Supplemental Table S2; https:// doi.org/10.3168/jds.2020-18883).

From the 20 articles kept for further analyses, 3,216 differentially expressed genes were identified when considering the 3 metabolic conditions (NEB and subclinical and clinical ketosis), and the transcriptomic and proteomic techniques. A total of 156 duplicate genes were removed from the gene list, and the 3,060 remaining genes were used to perform the subsequent analyses. Then, they were ordered by techniques, irrespective of the metabolic condition, resulting in the following number of genes per technique: (1) transcriptomic techniques: microarray $(\mathrm{n}=1,812)$; $\mathrm{qPCR}(\mathrm{n}=89)$; RNASeq $(\mathrm{n}=1,035)$, and $(2)$ proteomics $(\mathrm{n}=124$ genes).

From the 430 significant SNPs obtained from published GWAS, 24 of them were located within 14 differentially expressed genes (Table 1). This set of 24 
SNPs are located on chromosomes 2, 3, 6, 9, 11, 14, 27, and 29 and were selected from 3 different studies, which investigated milk levels of prognostic ketosis biomarkers (Tetens et al., 2015), candidate genes for ketosis resistance (Kroezen et al., 2018), and BHB concentration in milk (Nayeri et al., 2019) in dairy cattle.

From the permutation analysis, 3 significant metabolic pathways associated with 3 SNPs (rs41588443, rs378674931, and rs42197374) within 3 genes out of the 14 differentially expressed genes were identified for NEB and subclinical and clinical ketosis, namely "glyoxylate and dicarboxylate metabolism" (bta00630), "metabolic pathways" (bta01100), and "peroxisome" (bta04146; Table 2). The hydroxy acid oxidase 2, long chain (HAO2), acyl-CoA synthetase long chain family member 1 (ACSL1), and pyruvate carboxylase (PC) genes were involved in these pathways. The HAO2 gene was involved in all the significant pathways.

Venn diagrams showed that 10 common genes detected by published transcriptomic analysis were differentially expressed in the liver of dairy cows under NEB and subclinical and clinical ketosis (Figure 1A).

Table 1. Significant SNPs and their position within the start and end coordinates of each differentially expressed gene obtained through systematic review

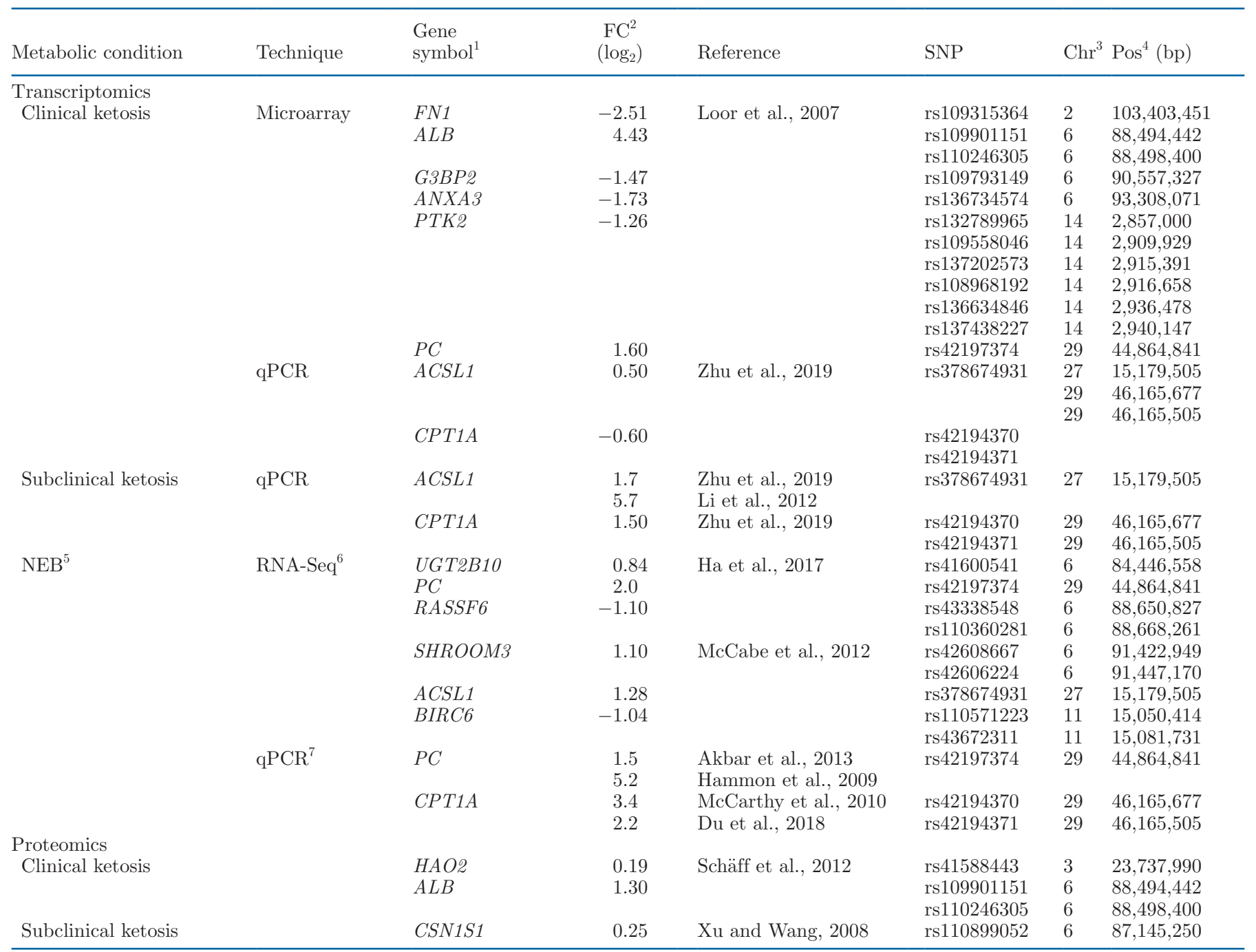

${ }^{1}$ Gene symbol = HUGO Gene Nomenclature Committee gene name.

${ }^{2} \mathrm{FC}=$ fold change.

${ }^{3} \mathrm{Chr}=$ chromosome.

${ }^{4} \mathrm{Pos}(\mathrm{bp})=$ position in base pairs.

${ }^{5} \mathrm{NEB}=$ negative energy balance.

${ }^{6}$ RNA-Seq $=$ RNA-sequencing.

${ }^{7} \mathrm{qPCR}=$ quantitative polymerase chain reaction. 
Table 2. Significant pathways, genes, and markers involved in ketosis from genome-wide association studies

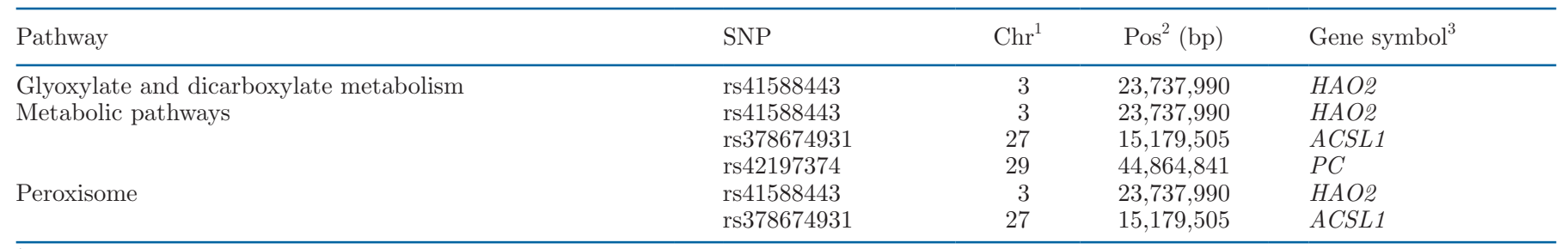

${ }^{1} \mathrm{Chr}=$ chromosome.

${ }^{2} \mathrm{Pos}=$ position.

${ }^{3}$ Gene symbol $=$ HUGO Gene Nomenclature Committee gene name.

This includes the ACSL1 (acyl-CoA synthetase long chain family member 1) gene, ACACA (acetyl-CoA carboxylase $\alpha$ ), FABP1 (fatty acid binding protein 1), PPARA (peroxisome proliferator activated receptor $\alpha), C P T 2$ (carnitine palmityl transferase 2), and the CPT1A (carnitine palmityl transferase 1A), DGAT1 (diacylglycerol O-acyltransferase 1), BAX (BCL2 associated $\mathrm{X}$, apoptosis regulator), TP53 (tumor protein P53), and the HMGCS1 (3-hydroxy-3-methylglutarylCoA synthase 1) genes. The highest number of common differentially expressed genes was observed between animals in NEB and clinical ketosis $(\mathrm{n}=133)$, whereas only 6 common genes were observed between animals under NEB and subclinical ketosis. These genes were p21 (cyclin-dependent kinase inhibitor 1), ACADL (acyl-CoA dehydrogenase long chain), MDM2 (MDM2 proto-oncogene), CASP 3 and CASP9 (caspase 3 and 9), and BCL2 (BCL2 apoptosis regulator; Supplemental Table S3; https://doi.org/10.3168/jds.2020-18883). Figure 1B shows the number of expressed genes in the liver of dairy cows detected by proteomic studies. The GSTA1 (glutathione S-transferase a 1) gene was the only one common gene among cows under NEB and subclinical and clinical ketosis conditions.

Figure 2A displays Venn diagrams showing the distribution of unique and common differentially expressed genes in dairy cows under NEB and subclinical and clinical ketosis detected by different transcriptomic techniques (microarray, qPCR, and RNA-Seq). Fourteen common genes were observed among the 3 techniques. Some of these genes, named $H R$ (HR lysine demethylase and receptor corepressor), NR4A1 (nuclear receptor subfamily 4 group A member 1 ), and PPARA (peroxisome proliferator activated receptor $\alpha$ ), are involved in DNA-binding transcription factor activity and transcription corepressor activity. The CPT1A and $C P T 1 B$ genes are involved in the transport of longchain fatty acids into the mitochondria for utilization as an energy source. The CD36 (CD36 molecule) and FADS2 (fatty acid desaturase 2) genes have roles in lipid metabolism, ion binding, and oxidoreductase activities. The APOA1 (apolipoprotein A1), ACADVL (acyl-CoA dehydrogenase very long chain), and SLC27A2 (solute carrier family 27 member A2) genes are involved in long-chain fatty acid-CoA ligase activity and lipid binding. In addition, the LPIN3 (lipin 3), ANGPTL4 (angiopoietin-like 4), $P C$ (pyruvate carboxylase), and $G P X 3$ (glutathione peroxidase 3) genes are related to transcription coactivator, enzyme inhibitor, and ligase and biotin carboxylase activities.

The highest number of commonly expressed genes (n $=125$ ) was obtained between microarray and RNA-Seq techniques. For qPCR and microarray techniques, 28 common genes were found (Supplemental Table S3).

Figure $2 \mathrm{~B}$ shows the number of unique and common differentially expressed genes identified in transcriptomic studies and proteomic studies. A total of 47 genes were detected in both transcriptomic and proteomic studies. Transcriptomic techniques identified a higher number of unique genes $(\mathrm{n}=2,693)$ than proteomics techniques $(\mathrm{n}=77)$.
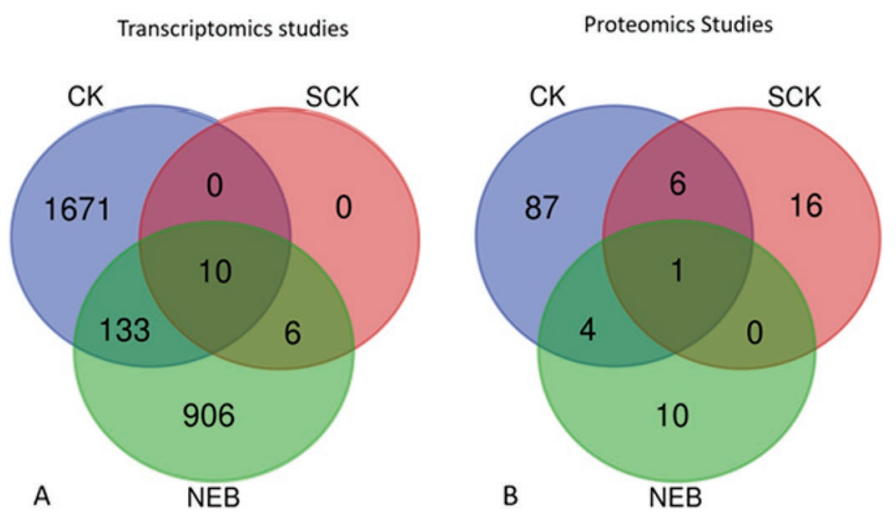

Figure 1. Venn diagrams depicting genes differentially expressed in the liver of dairy cows under negative energy balance (NEB), subclinical ketosis (SCK), and clinical ketosis (CK). (A) Depicts the genes found in transcriptomic studies. (B) Depicts the genes found in proteomic studies. 
When analyzing which genes were identified as differentially expressed during clinical ketosis by different techniques, a much larger number of genes were detected using microarrays than using $\mathrm{qPCR}$ and RNA-Seq approaches (Figure 3A). However, $63.6 \%$ of the differentially expressed genes identified by qPCR were also detected in studies that used a microarray technique. The RNA-Seq method had the smallest sample set $(\mathrm{n}=26)$, but $42.3 \%$ of the detected genes were also identified as differentially expressed in studies that used microarray or qPCR approaches. No common genes were detected by all 3 techniques.

Figure 3B shows the number of differentially expressed genes in cows under the NEB condition detected different techniques. The PPARA gene was the only gene detected by all 3 techniques (i.e., microarray, $\mathrm{qPCR}$, and RNA-Seq). This gene acts in the peroxisome pathway, which is related to ketosis, and could be a key gene in ketosis development. Additionally, FABP1 (fatty acid binding protein 1) and CPT1A (carnitine palmitoyltransferase 1A) are important genes in the regulation of lipid metabolism that were detected using microarray and qPCR techniques. The genes ACACA and ACSL1 were also identified by more than one technique (qPCR and RNA-Seq).

\section{Functional Enrichment Analysis}

Figure 4 presents the gene network for the 14 differentially expressed genes with significant SNPs for NEB and subclinical and clinical ketosis (Table 1). The functional enrichment analysis identified 20 additional genes linked via various interaction types (co-expression, metabolic pathway, shared protein domains, colocalization, predicted physical interactions, genetic interactions, or a combination of these) to the 14 differentially expressed genes. However, only co-expression
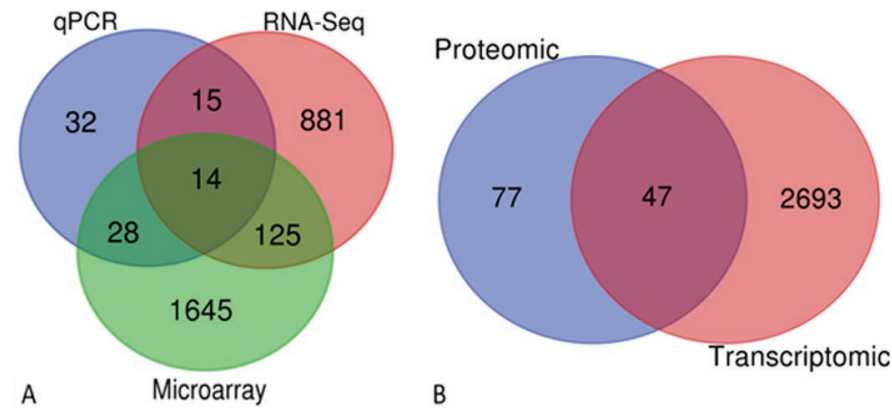

B

Figure 2. Venn diagrams depicting differentially expressed genes detected using gene expression analysis in dairy cattle under negative energy balance, and subclinical and clinical ketosis conditions. (A) Number of common genes among transcriptomic techniques. (B) Number of common genes between transcriptomic and proteomic studies. Seq = sequencing; $\mathrm{qPCR}=$ quantitative $\mathrm{PCR}$.
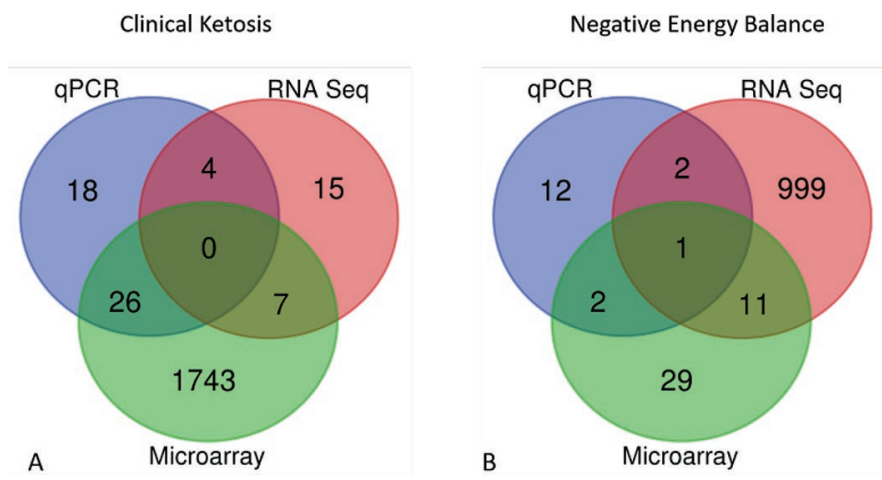

Figure 3. Number of common differentially expressed genes detected by different techniques in dairy cattle under negative energy balance (NEB) and clinical ketosis conditions. (A) Genes detected in the clinical ketosis condition. (B) Genes detected in the NEB condition. Seq = sequencing; $\mathrm{qPCR}=$ quantitative $\mathrm{PCR}$.

links were highlighted on the network in Figure 4 to provide a clearer view of the genes that showed correlated expression levels for NEB and subclinical and clinical ketosis in dairy cattle.

The 20 additional linked genes did not harbor any significant SNPs from the published GWAS. The 6 genes (G3BP2, CPT1C, CPT1B, FABP6, CHRNB1, and $P P A R D)$ arranged in a column in the right side of Figure 4 were associated with the 14 differentially expressed genes (Table 1) via different biological functions related to ketosis development in dairy cattle (Figure 4). In addition, out of the 34 genes in Figure 4, 25 genes harbored SNPs included in the Illumina bovine SNP60 (60K, 57,798 SNPs) BeadChip (Illumina Inc., San Diego, CA), as shown in Table 3.

The 34 genes in Figure 4 were mainly involved in 7 significant functions (false discovery rate $<0.05$ ): fatty acid transport, long-chain fatty acid transport, lipid transport, lipid localization, fatty acid metabolic process, long-chain fatty acid-CoA ligase activity, and fatty acid transmembrane transport. These genes might be good potential candidate genes to enhance cows' resistance to the development of ketosis.

\section{QTL Enrichment Analysis}

A total of 2,000 annotated QTL from the cattle QTL database (Hu et al., 2013) overlapped with the 14 differentially expressed genes harboring 24 SNPs (Table 1). These QTL pertained to 6 different phenotypic classes (production, health, milk, exterior, reproduction, and meat and carcass). From these annotated QTL, 85.15\% were associated with the "milk" class of QTL and $6.4 \%$ with the class "health" (Figure 5). The differentially expressed genes FN1 and PTK2 were enriched for QTL previously described for the traits "ketosis" on chro- 
mosome 2 and "milk iron content" on chromosome 14, respectively. Regarding the QTL health class, from the 2,000 annotated QTL, $0.45 \%$ of the QTL were partly associated with ketosis (Figure 6).

\section{DISCUSSION}

Gene expression and GWAS analyses are 2 complementary approaches to determine the genetic background of traits of interest. Here, potential candidate genes associated with NEB and subclinical, and clinical ketosis were identified by combining the results obtained from a systematic review of genomic, transcriptomic, and proteomic studies. From the 14 differentially expressed genes identified by this study $(A L B, C P T 1 A$, PC, UGT2B10, SHROOM3, FN1, G3BP2, ANXA3, PTK2, ACSL1, BIRC6, CSN1S1, HAO2, and RASSF6), the FN1 (fibronectin 1), ACSL1 (acyl-CoA synthetase long chain family member 1 ), $P C$ (pyruvate carboxylase), and CPT1A (carnitine palmityl transferase 1A) genes were previously reported to be associated with all 3 metabolic conditions. As described by Graber et al. (2010), an increased expression of ACSL1, PC, and $C P T 1 A$ genes, associated with an increase in the fatty acid $\beta$-oxidation in dairy cows, may occur due to an elevated level of NEFA during NEB postpartum.

The ACSL1 protein activates fatty acids to acyl-CoA, and it is involved in fatty acid transport across the plasma membrane, providing substrates for metabolic pathways that catabolize fatty acids or synthesize complex lipids (de Jong et al., 2007; Li et al., 2009). Ellis et al. (2010, 2011) studied the metabolic and tissuespecific regulation of acyl-CoA metabolism in mice. They reported the tissue-dependent effect of ACSL1 on fatty acid metabolism in the liver and the severe inhibition of fatty acid oxidation in muscle and adipose tissues that occurs when this gene is not expressed. Zhu et al. (2019) studied the expression patterns of hepatic genes involved in lipid metabolism in dairy cows with subclinical or clinical ketosis. They reported that the expression of the ACSL1 gene was significantly higher in both subclinical and clinical ketosis than in the control group. Furthermore, these authors suggested that hepatic fatty acid uptake, transport, and activation are

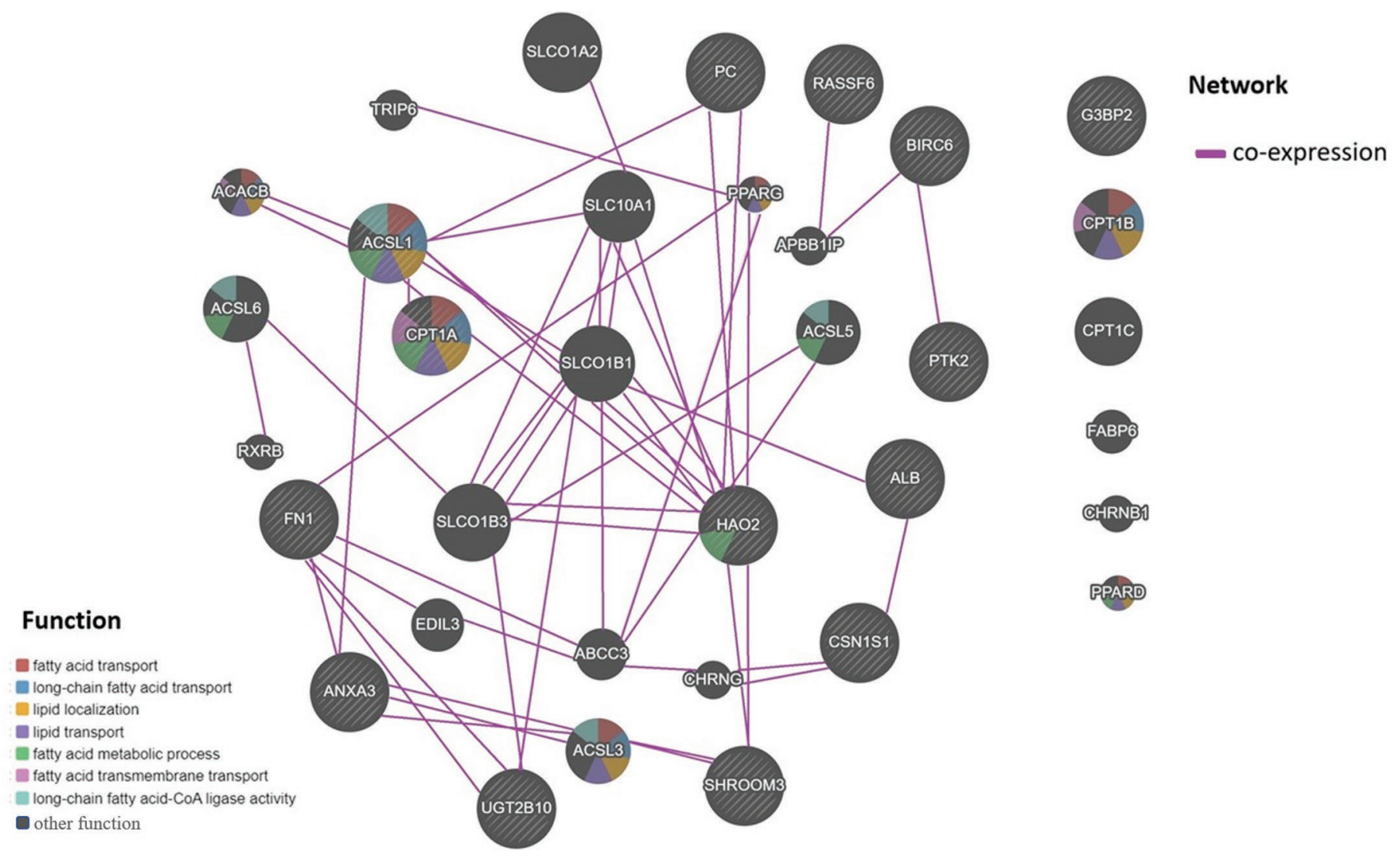

Figure 4. Network integration of candidate genes related to negative energy balance, and subclinical and clinical ketosis in dairy cattle. The color pie charts show the biological function associated (false discovery rate $<0.05$ ) with the genes presented in the network, and the gray pie charts indicate that these genes were not associated with any of the analyzed biological functions. The light gray stripes inside the pies indicate the 14 differentially expressed genes used as input for the network. 
Table 3. Significant differentially expressed genes with significant SNPs in published GWAS for negative energy balance (NEB), subclinical and clinical ketosis, chromosome, SNP identification, SNP position, and number of SNPs harbored by the genes included in the Illumina bovine SNP60 BeadChip (Illumina Inc., San Diego, CA)

\begin{tabular}{|c|c|c|c|c|}
\hline Gene symbol $^{1}$ & $\mathrm{Chr}^{2}$ & SNP identification & $\operatorname{Pos}^{3}(\mathrm{bp})$ & Number of SNPs ${ }^{4}$ \\
\hline$R X R B$ & 23 & - & - & - \\
\hline FN1 & 2 & rs109315364 & $103,403,451$ & 2 \\
\hline \multirow[t]{2}{*}{$A L B$} & 6 & rs109901151 & $88,494,442$ & 1 \\
\hline & & rs110246305 & $88,498,400$ & \\
\hline$F A B P 6$ & 5 & - & _ & - \\
\hline G3BP2 & 6 & rs109793149 & $90,557,327$ & 2 \\
\hline$A N X A 3$ & 6 & rs136734574 & $93,308,071$ & 1 \\
\hline \multirow[t]{6}{*}{ PTK2 } & 14 & rs132789965 & $2,857,000$ & 16 \\
\hline & & rs109558046 & $2,909,929$ & \\
\hline & & rs137202573 & $2,915,391$ & \\
\hline & & rs108968192 & $2,916,658$ & \\
\hline & & rs136634846 & $2,936,478$ & \\
\hline & & rs137438227 & $2,940,147$ & \\
\hline$P C$ & 29 & rs42197374 & $44,864,841$ & 2 \\
\hline$A C A C B$ & 17 & - & - & 1 \\
\hline UGT2B10 & 6 & rs41600541 & $84,446,558$ & 1 \\
\hline \multirow[t]{2}{*}{$R A S S F 6$} & 6 & rs43338548 & $88,650,827$ & 2 \\
\hline & & rs110360281 & $88,668,261$ & \\
\hline \multirow[t]{2}{*}{ SHROОМЗ } & 6 & rs42608667 & $91,422,949$ & 7 \\
\hline & & rs42606224 & $91,447,170$ & \\
\hline ACSL5 & 26 & - & - & 3 \\
\hline \multirow[t]{2}{*}{ BIRC6 } & 11 & rs110571223 & $15,050,414$ & 10 \\
\hline & & rs43672311 & $15,081,731$ & \\
\hline HAO2 & 3 & rs41588443 & $23,737,990$ & 1 \\
\hline CSN1S1 & 6 & rs110899052 & $87,145,250$ & 1 \\
\hline$A C S L 1$ & 27 & rs378674931 & $15,179,505$ & 4 \\
\hline \multirow[t]{2}{*}{ CPT1A } & 29 & rs42194370 & $46,165,677$ & 6 \\
\hline & & rs42194371 & $46,165,505$ & \\
\hline EDIL3 & 5 & - & - & 10 \\
\hline CPT1C & 18 & - & - & - \\
\hline CPT1B & 5 & - & - & - \\
\hline ACSL6 & 7 & - & - & 2 \\
\hline ACSL3 & 2 & - & - & 1 \\
\hline ABCC3 & 19 & - & - & 5 \\
\hline TRIP6 & 25 & - & - & - \\
\hline$A P B B 1 I P$ & 13 & - & - & 1 \\
\hline$C H R N G$ & 2 & - & - & - \\
\hline CHRNB1 & 19 & - & - & - \\
\hline$P P A R G$ & 22 & - & - & 4 \\
\hline PPARD & 23 & - & - & 3 \\
\hline SLCO1A2 & 5 & - & - & 1 \\
\hline SLCO1B3 & 5 & - & - & 2 \\
\hline SLCO1B1 & 12 & - & - & - \\
\hline SLCO10A1 & 14 & - & - & - \\
\hline
\end{tabular}

${ }^{1}$ Gene symbol $=$ HUGO Gene Nomenclature Committee gene name.

${ }^{2} \mathrm{Chr}=$ chromosome.

${ }^{3} \mathrm{Pos}=\mathrm{SNP}$ position.

${ }^{4}$ Number of SNPs included in the Illumina bovine SNP60 BeadChip.

significantly increased in cows with subclinical ketosis and clinical ketosis. Li et al. (2012) also reported that the expression level of ACSL1 was significantly increased in cows with subclinical ketosis, with the highest gene expression value (fold change $\log _{2}=+5.7$ ) for subclinical ketosis. Subclinically affected cows have an increased chance of developing clinical ketosis and are less fertile than animals with normal serum ketone body concentrations (Rutherford et al., 2016).
The CPT1A gene has been associated with ketosis in dairy cattle. The carnitine palmitoyltransferase (CPT) system is responsible for the transport of fatty acids into the mitochondria (Cobb and Dukes, 1998). The CPT1 is one of the 3 enzymes that compose the CPT system and has a crucial role in the regulation of longchain fatty acid metabolism (McGarry and Brown, 1997). Previous studies investigated the activity and function of $C P T 1$ in ruminants at the various stages of 


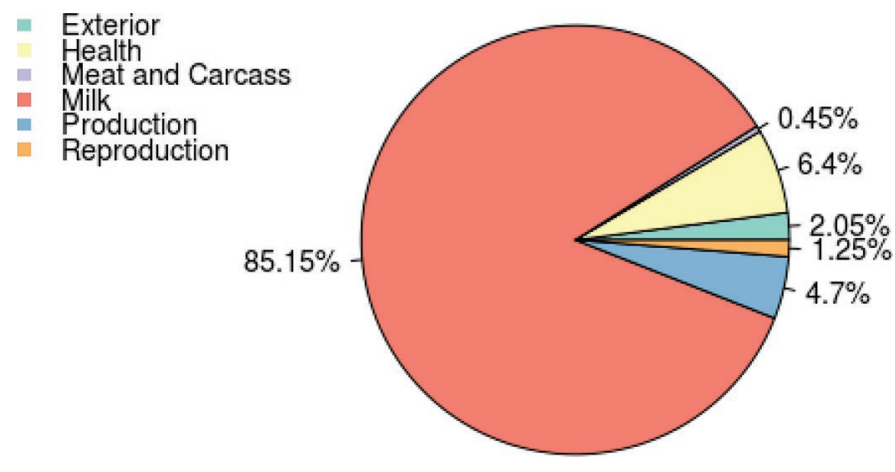

Figure 5. Pie chart for 2,000 annotated QTL that overlap with the 14 differentially expressed genes identified for negative energy balance and subclinical and clinical ketosis in dairy cattle. The different colors in the pie chart show the phenotypic trait classes associated with the QTL, and the numbers are the corresponding QTL frequencies.

lactation in an attempt to better understand metabolic changes during ketosis and hepatic lipidosis (Knapp, 1990; Mizutani et al., 1999). Aiello et al. (1984) showed that the higher gluconeogenesis and ketogenesis may be associated with higher activity of CPT1 in early lactation in dairy cows, which is possibly due to greater NEB. Knapp (1990) investigated nonketotic, nonlactating, and lactating dairy cows and reported no difference in CPT1 activity. Similar results were shown by Mizutani et al. (1999), who reported no difference in CPT1 activity in cows in early, mid, and late lactation. Dann and Drackley (2005), investigating how prepartum nutrient intake and postpartum health status affect hepatic CPT1 activity, reported that alterations of this gene may not be involved in the etiology of ketosis in dairy cows. Kroezen et al. (2018) identified 4 SNPs located within the CPT1A gene associated with the first lactation EBV for ketosis.

The $P C$ gene is highly expressed in adipose tissue and is involved in fatty acid synthesis by providing oxaloacetate for conversion into citrate, which is cleaved to form oxaloacetate and acetyl-CoA (Ballard and Hanson, 1967). In the liver, the lack of oxaloacetate prevents the oxidation of acetyl-CoA produced from pyruvate and fatty acids and the excess of acetyl-CoA results in hepatic ketone body synthesis (DeVivo et al., 1977). Thus, pyruvate carboxylase produces oxaloacetate from pyruvate, which is a critical anaplerotic reaction that affects the capacity of the tricarboxylic acid cycle and supports the cataplerotic reactions of gluconeogenesis and fatty acid synthesis (Owen et al., 2002). The $P C$ gene plays a crucial role in hepatic gluconeogenesis to ensure a high level of glucose during early lactation for milk production (Baird et al., 1968; Aschenbach et al., 2010). Previous studies highlighted the importance of gluconeogenesis in supporting the immediate meta- bolic requirements of dairy cows at calving (Bell, 1995; Danfaer et al., 1995). Weber et al. (2013) reported an increase of hepatic expression of $P C$ immediately at parturition. The deficiency of $P C$ is associated with an increase in the ratio of acetoacetate and 3-hydroxybutyrate, resulting in a low NADH to NAD ratio inside the mitochondria.

The FN1 gene encodes a glycoprotein component of the extracellular matrix, which is associated with cell signaling and lipid metabolism (Loor et al., 2007). This protein has been shown to be differentially expressed in the liver of ketotic cows, but the interaction mechanism of FN1 with ketosis has not been established (Loor et al., 2007; Buitenhuis et al., 2013).

In addition to the 4 genes described above (CPT1A, $P C, F N 1$, and ACSL1), other genes can be highlighted as potentially associated with NEB and subclinical and clinical ketosis, namely the CSN1S1 ( $\alpha_{S 1}$-casein $)$ and HAO2 genes. The CSN1S1 gene encodes $\alpha_{S 1}$-casein, one of the main proteins in milk, and has 2 significant SNPs within its promoter region, which were associated with milk yield traits in German Angeln dairy cattle in a QTL mapping study (Sanders et al., 2006). Although most of the literature shows that the expression of this gene occurs in the epithelial cells of the mammary gland, Vordenbäumen et al. (2011) collected evidence that this gene can be expressed in human monocytes and has immunomodulatory properties. The $\alpha_{\mathrm{S1}}$-casein has also been shown to exhibit chaperone-like activity (Bhattacharyya and Das 1999), which makes possible for it to stabilize other milk caseins. Thus, the protein encoded by the CSN1S1 gene has functions that go beyond nutritional aspects, and this gene may be expressed in other cells of the body in stressful situations, which needs to be further investigated.

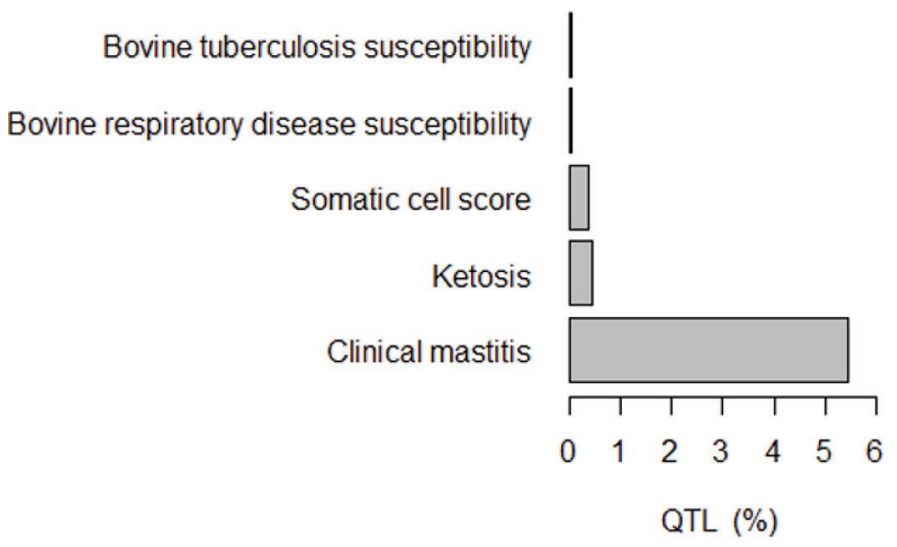

Figure 6. Specific QTL categories associated with the health QTL class out of 2,000 annotated QTL that overlap with the 14 differentially expressed genes identified for negative energy balance and subclinical and clinical ketosis in dairy cattle. 
The HAO2 gene product in humans is localized in the peroxisomes and is involved in the oxidation of longchain fatty acids, such as 2-hydroxypalmitate, and is highly expressed in the liver and kidney (Jones et al., 2000). As mentioned earlier, ketosis has been associated with the development of fatty liver in cows. This state happens when the hepatic uptake of NEFA exceeds its oxidation (Drackley et al., 2001). The increase in the expression of the HAO2 gene in cows with clinical ketosis is consistent with the metabolic situation of these animals, but it may still not be enough to help reverse this state (Schäff et al., 2012). The understanding of the fluctuations of the expression HAO2 gene in the development of ketosis needs to be better investigated by further experimental studies.

A permutation approach was used to identify the metabolic pathways associated with the 14 differentially expressed genes investigated. For all genes, patterns of pathways associated with different types of ketosis and NEB were identified. In the glyoxylate cycle, key enzymes isocitrate lyase and malate synthase convert isocitrate, and acetyl-CoA into succinate and malate. Thus, the glyoxylate cycle acts as a link between catabolic activities and biosynthetic capacities, enabling cells to use fatty acids or C2-units, such as acetate or ethanol, as a carbon source. The "glyoxylate and dicarboxylate metabolism" pathway was previously associated with the production of ketone bodies due to a deficit in the utilization of glucose, resulting in fatty acid oxidation and decomposition in mice (Song et al., 2015).

One of the processes involved in the "glyoxylate and dicarboxylate metabolism" pathway is "pyruvate metabolism," which is associated with the production of formate. A previous study found decreased levels of formic acid in dairy cows with clinical ketosis, indicating that the generation of formate from pyruvic acid decreased. Instead, the pyruvic acid was converted to acetyl-CoA, which resulted in ketogenesis and elevated blood ketone content (Wang et al., 2016). The HAO2 gene was present in all 3 significant pathways reported in this study, highlighting its possible association with NEB and subclinical and clinical ketosis.

The metabolic pathways found significantly associated with ketosis in this study were consistent with their biological role. Ketosis is a major metabolic disorder, which is often observed when the gluconeogenic capacity in the liver fails to meet the increased tissue demands for glucose in dairy cattle (Aschenbach et al., 2010). Thus, the rapid adaptation of key metabolic pathways in the liver is important for the cows to make a proper transition to support lactation. This study also raised other questions that may be investigated in future studies. For instance, the expression pattern of the 14 genes highlighted in this study could be further investigated to determine if they would have the same expression pattern in animals that normally recover from the NEB status compared with those animals that fail to recover.

The biological aspects involved in the pathogenesis of bovine ketosis is not completely understood. However, it is well known that there is a combination of intense adipose tissue mobilization and high glucose demand, mainly in early lactation (Weber et al., 2013). Adipose tissue mobilization is accompanied by high blood serum concentrations of nonesterified fatty acids (NEFA; Adewuyi et al., 2005). The "peroxisome" pathway includes fatty acid-oxidation metabolism and is considered an alternate pathway for hepatic oxidation of NEFA, showing a considerable capacity for $\beta$-oxidation in liver tissues of cows (Drackley et al., 2001). The presence of an elevated concentration of NEFA in hepatic tissue in postpartum dairy cows is one of the more obvious biochemical features of ketosis (Emery et al., 1992; Reynolds et al., 2003). Grum et al. (1996) demonstrated that esterification of palmitate by liver slices increased significantly at $1 \mathrm{~d}$ after calving compared with $21 \mathrm{~d}$ before or $21 \mathrm{~d}$ after calving, suggesting that additional fat fed to cows during the prepartum period does not decrease plasma NEFA concentrations. However, Douglas et al. $(1998,2002)$ found that the reduction in liver triglycerides was largely attributable to the decreased DMI in cows fed with fat during the dry period, resulting in a decrease in peripartal NEFA concentrations in plasma.

Once absorbed by the liver, fatty acids are $\beta$-oxidized to acetyl-CoA, which will undergo complete oxidation through the tricarboxylic acid cycle, incomplete oxidation through ketogenesis, or synthesis of triglycerides and packing as very low density lipoprotein for export from the liver, or storage as liver lipids (Grummer, 1993). When the levels of acetyl-CoA exceed the capacity of the tricarboxylic acid cycle, there is increased production of ketone bodies and deposition of triglycerides. Thus, fatty acid metabolism in the liver and the development of ketosis are closely related (Grummer, 1993).

Based on Venn intersections, 10 differentially expressed genes were found in common for NEB and subclinical and clinical ketosis in liver tissue of dairy cows (ACSL1, ACACA, FABP1, HMGCS1, CPT2, CPT1A, $D G A T 1, T P 53, B A X$, and PPARA; Figure 1). All these genes are involved in the pathway of lipid metabolism regulated by PPARA (peroxisome proliferator-activated receptor alpha). The highest number of commonly expressed genes $(\mathrm{n}=133)$ was obtained between NEB and clinical ketosis, since these are the 2 most explored metabolic states in terms of gene expression. Negative 
energy balance is a common status among dairy cows in the first few weeks of lactation, but most of the cows recover from this period through metabolic adaptation (Sundrum, 2015). Thus, an important goal is to be better understand how the expression of these genes in animals that naturally recover from the NEB differs from the expression in those animals that do not recover. Unfortunately, the available data in the literature were limited to allow for a better understanding of these differences.

The interaction gene-gene network (Figure 4) performed for the 14 differentially expressed genes revealed that these genes were co-expressed with 20 other genes. This analysis revealed that the ACSL1 gene showed the highest number of co-expression interactions (7 links). This gene was co-expressed with 7 other genes, and among them, the genes $C P T 1 A, P C, A C A C B$, and HAO2 are known to play critical roles in fatty acid metabolic processes (Zhu et al., 2019). In addition, the $A C S L 5$ gene was co-expressed with the SLCO1B3 and $A B C C 3$ genes. Therefore, the results show that the ACSL family has an important connective role in the network, suggesting that it might play a central role in the occurrence of ketosis.

Besides the 430 significant SNPs from published GWAS, SNPs from the $60 \mathrm{~K}$ Illumina panel were also investigated for the 34 genes in the network in Figure 4. In total, 25 genes in the network harbored 89 SNPs included in the 60K Illumina SNP panel (Table 3). From the 89 SNPs, the genes CPT1A and ACSL1 harbored 6 and 4 SNPs, respectively. The ACSL1 gene was co-expressed with the CPT1A gene. These 2 genes are involved in the oxidation of fatty acids and ketone body synthesis; as previously reported in this study, the expression of $A C S L 1$ and CPT1A genes was significantly increased for subclinical ketosis in dairy cows (Zhu et al., 2019). Ellis et al. (2010) reported an $80 \%$ lower ACSL specific activity in adipose-specific $A C S L 1$ knockout mice $\left(\mathrm{Acsl1}^{\mathrm{A}-/-}\right)$ than in the control group (Acsl1 $\left.{ }^{\text {flox/flox }}\right)$, which showed that this gene has different expression patterns and activity between ruminants and nonruminants. The identification of SNPs specifically associated with the studied traits highlights the importance of investigating these key genes. These SNPs are associated with important pathways (Table 2), which are directly related to biological mechanisms (i.e., fatty acid metabolism) potentially involved in the pathogenesis of ketosis. Thus, these SNPs might be potential candidates to be further investigated for their roles in ketosis susceptibility since these SNPs were located in coding regions of key genes that are differentially expressed in the liver of dairy cows under NEB and subclinical or clinical ketosis.
As expected for a trait with a low heritability and a highly polygenic architecture, such as ketosis, for the 10 main genes, a considerable number of genes were involved in the network, with several connections. The results from gene network analysis suggest the potential association of the identified genes with fatty acid metabolism underlying NEB and subclinical and clinical ketosis.

In this study, the genes FN1 and PTK2 (protein tyrosine kinase 2) were enriched for QTL previously described for ketosis and milk iron content, respectively, which is interesting because, as previously discussed, the interaction mechanism of FN1 with ketosis has not been established despite its known function in lipid metabolism in ketotic cows (Loor et al., 2007). The FN1 gene was enriched for QTL at $103 \mathrm{~kb}$ on chromosome 2 harboring one SNP (rs109315364), whereas the PTK2 gene was enriched for QTL around 28 to $29 \mathrm{~kb}$ on chromosome 14, harboring 6 SNPs (rs132789965, rs109558046, rs137202573, rs108968192, rs136634846, and rs137438227). These observations suggest that these genes could be considered as candidate genes for further investigation.

To our knowledge, this study is the first to assess the overlap between published gene expression and GWAS results for NEB and subclinical and clinical ketosis in dairy cattle.

\section{CONCLUSIONS}

The findings in this investigation suggest that metaanalysis of gene expression studies combined with genome-wide association studies can contribute to a better understanding of the genetic background of negative energy balance and subclinical and clinical ketosis in dairy cattle. This investigation also identified the scarcity of studies on differentially expressed genes in the liver of cows during the transition period. Among the 3 metabolic conditions, the state of subclinical ketosis had the fewest candidate genes reported in the literature. This study highlighted 14 genes (ACSL1, $A L B, \quad A N X A 3, \quad B I R C 6, \quad C P T 1 A, \quad C S N 1 S 1, \quad F N 1$, G3BP2, HAO2, PC, PTK2, RASSF6, SHROOM3, and $U G T 2 B 10)$ that harbor significant polymorphisms in reported genome-wide association studies; these polymorphisms have great potential to be used as molecular markers in animal breeding programs for selection for cows less susceptible to ketosis. In addition, the genes FN1 and PTK2 were enriched for QTL for ketosis and should be considered as candidate genes for further investigation. These findings may improve the understanding of negative energy balance and ketosis in dairy cows, which could enhance selection decisions and help 
with the development of biomarkers for early diagnosis and prevention of ketosis.

\section{ACKNOWLEDGMENTS}

This work was supported by funding from the DairyGen Council of Canadian Dairy Network and a Collaborative Research and Development grant from the Natural Science and Engineering Research Council of Canada. F. Schenkel and G. Vargas thank the financial support in main part by Agriculture and Agri-Food Canada, and by additional contributions from Dairy Farmers of Canada, the Canadian Dairy Network (Guelph, ON, Canada), and the Canadian Dairy Commission under the Agri-Science Clusters Initiative. As per the research agreement, aside from providing financial support, the funders have no role in the design and conduct of the studies, data collection and analysis, or interpretation of the data. Researchers maintain independence in conducting their studies, own their data, and report the outcomes regardless of the results. The decision to publish the findings rests solely with the researchers. The authors have not stated any conflicts of interest.

\section{REFERENCES}

Adewuyi, A. A., E. Gruys, and F. J. C. M. Van Eerdenburg. 2005. Non esterified fatty acids (NEFA) in dairy cattle. A review. Vet. Q. 27:117-126. https://doi.org/10.1080/01652176.2005.9695192.

Aiello, R. J., T. M. Kenna, and J. H. Herbein. 1984. Hepatic gluconeogenesis and ketogenic interrelationships in the lactating cow. J. Dairy Sci. 67:1707-1715.

Akbar, H., M. Bionaz, B. Carlson, S. L. Rodriguez-Zas, R. E. Everts, H. A. Lewin, J. K. Drackley, and J. J. Loor. 2013. Feed restriction, but not L-carnitine infusion, alters the liver transcriptome by inhibiting sterol synthesis and mitochondrial oxidative phosphorylation and increasing gluconeogenesis in mid-lactation dairy cows. J. Dairy Sci. 96:2201-2213. https://doi.org/10.3168/jds.2012-6036.

Andersson, L. 1988. Subclinical ketosis in dairy cows. Vet. Clin. North Am. Food Anim. Pract. 4:233-251. https://doi.org/10.1016/S0749 -0720(15)31046-X

Aschenbach, J. R., N. B. Kristensen, S. S. Donkin, H. M. Hammon, and G. B. Penner. 2010. Gluconeogenesis in dairy cows: The secret of making sweet milk from sour dough. IUBMB Life 62:869-877. https://doi.org/10.1002/iub.400.

Baird, G. D., K. G. Hibbitt, G. D. Hunter, P. Lund, M. Stubbs, and H. A. Krebs. 1968. Biochemical aspects of bovine ketosis. Biochem. J. 107:683-689. https://doi.org/10.1042/bj1070683.

Ballard, F. J., and R. W. Hanson. 1967. The citrate cleavage pathway and lipogenesis in rat adipose tissue: Replenishment of oxaloacetate. J. Lipid Res. 8:73-79.

Bell, A. W. 1995. Regulation of organic nutrient metabolism during transition from late pregnancy to early lactation. J. Anim. Sci. 73:2804-2819. https://doi.org/10.2527/1995.7392804x.

Bhattacharyya, J., and K. P. Das. 1999. Molecular chaperone-like properties of an unfolded protein, alpha(s)-casein. J. Biol. Chem. 274:15505-15509. https://doi.org/10.1074/jbc.274.22.15505.

Biswal, S., D. C. Nayak, and K. K. Sardar. 2016. Prevalence of ketosis in dairy cows in milk shed areas of Odisha state, India. Vet. World 9:1242-1247. https://doi.org/10.14202/vetworld.2016.1242-1247.

Buitenhuis, A. J., U. K. Sundekilde, N. A. Poulsen, H. C. Bertram, L. B. Larsen, and P. Sorensen. 2013. Estimation of genetic pa- rameters and detection of quantitative trait loci for metabolites in Danish Holstein milk. J. Dairy Sci. 96:3285-3295. https://doi.org/ 10.3168/jds.2012-5914.

Cabrera, C. P., P. Navarro, and C. S. Haley. 2016. genomicper: Circular genomic permutation using GWAS P-values of association. $\mathrm{R}$ package version 1.6. https://CRAN.R-project.org/package= genomicper.

Cabrera, C. P., P. Navarro, J. E. Huffman, A. F. Wright, C. Hayward, H. Campbell, J. F. Wilson, I. Rudan, N. D. Hastie, V. Vitart, and C. S. Haley. 2012. Uncovering networks from genome-wide association studies via circular genomic permutation. G3 (Bethesda) 2:1067-1075. https://doi.org/10.1534/g3.112.002618.

Cánovas, A., A. Reverter, K. L. DeAtley, R. L. Ashley, M. L. Colgrave, M. R. S. Fortes, A. Islas-Trejo, S. Lehnert, L. Porto-Neto, G. Rincón, G. A. Silver, W. M. Snelling, J. F. Medrano, and M. G. Thomas. 2014. Multi-tissue omics analyses reveal molecular regulatory networks for puberty in composite beef cattle. PLoS One 9 https://doi.org/10.1371/journal.pone.0102551.

Carlson, M. R., H. Pagès, S. Arora, V. Obenchain, and M. Morgan. 2016. Genomic annotation resources in R/Bioconductor. Methods Mol. Biol. 1418:67-90. https://doi.org/10.1007/978-1-4939-3578-9 4.

Cobb, J., and I. Dukes. 1998. Recent advances in the development of agents for the treatment of type 2 diabetes. Annu. Rep. Med. Chem. 33:213-222.

Danfaer, A., V. Tetens, and N. Agergaard. 1995. Review and an experimental study on the physiological and quantitative aspects of gluconeogenesis in lactating ruminants. Comp. Biol. Chem. Physiol. 111B:201-210. https://doi.org/10.1016/0305-0491(94)00242-M.

Dann, H. M., and J. K. Drackley. 2005. Carnitine palmitoyltransferase I in liver of periparturient dairy cows: Effects of prepartum intake, postpartum induction of ketosis, and periparturient disorders. J. Dairy Sci. 88:3851-3859. https://doi.org/10.3168/jds .S0022-0302(05)73070-8.

de Jong, H., A. C. Neal, R. A. Coleman, and T. M. Lewin. 2007. Ontogeny of mRNA expression and activity of long-chain acylCoA synthetase (ACSL) isoforms in Mus musculus heart. Biochim. Biophys. Acta 1771:75-82. https://doi.org/10.1016/j.bbalip.2006 .11.007.

DeVivo, D.C., M. W. Haymond, M. P. Leckie, Y. L. Bussman, D B. McDougal Jr., and A. S. Pagliara. 1977. The clinical and biochemical implications of pyruvate carboxylase deficiency. J. Clin. Endocrinol. Metab. 45:1281-1296. https://doi.org/10.1210/jcem $-45-6-1281$

Ellis, J., L. Li, P. Wu, T. Koves, O. Ilkayeva, R. D. Stevens, S. M. Watkins, D. M. Muoio, and R. A. Coleman. 2010. Adipose acyl-CoA synthetase-1 (ACSL1) directs fatty acids towards $\beta$-oxidation and is required for cold thermogenesis. Cell Metab. 12:53-64.

Douglas, G. N., J. K. Drackley, T. R. Overton, and H. G. Bateman. 1998. Lipid metabolism and production by Holstein cows fed control or high fat diets at restricted or ad libitum intakes during the dry period. J. Dairy Sci. 81(Suppl. 1):295. (Abstr.)

Douglas, G. N., J. Rehage, A. D. Beaulieu, A. O. Bahaa, and J. K. Drackley. 2002. Peripartal changes in fatty acid profiles of blood, adipose tissue, and liver of dairy cows can be modulated by diet. J. Dairy Sci. 85(Suppl. 1):185. (Abstr.)

Drackley, J. K., T. R. Overton, and G. N. Douglas. 2001. Adaptations of glucose and long-chain fatty acid metabolism in liver of dairy cows during the periparturient period. J. Dairy Sci. 84:E100-E112. https://doi.org/10.3168/jds.S0022-0302(01)70204-4.

Du, X., T. Shen, H. Wang, X. Qin, D. Xing, Q. Ye, Z. Shi, Z. Fang, Y. Zhu, Y. Yang, Z. Peng, C. Zhao, B. Lv, X. Li, G. Liu, and X. Li. 2018. Adaptations of hepatic lipid metabolism and mitochondria in dairy cows with mild fatty liver. J. Dairy Sci. 101:9544-9558. https://doi.org/10.3168/jds.2018-14546.

Ellis, J., L. Li, P. Wu, T. Koves, O. Ilkayeva, R. D. Stevens, S. M. Watkins, D. M. Muoio, and R. A. Coleman. 2010. Adipose acyl-CoA synthetase-1 (ACSL1) directs fatty acids towards $\beta$-oxidation and is required for cold thermogenesis. Cell Metab. 12:53-64. https:// doi.org/10.1016/j.cmet.2010.05.012. 
Ellis, J. M., S. M. Mentock, M. A. DePetrillo, T. R. Koves, S. Sen, S. M. Watkins, D. M. Muoio, G. W. Cline, H. Taegtmeyer, G. I. Shulman, M. S. Willis, and R. A. Coleman. 2011. Mouse cardiac acyl coenzyme a synthetase 1 deficiency impairs fatty acid oxidation and induces cardiac hypertrophy. Mol. Cell. Biol. 31:1252-1262. https://doi.org/10.1128/MCB.01085-10.

Emery, R. S., J. S. Liesman, and T. H. Herdt. 1992. Metabolism of long chain fatty acids by ruminant liver. J. Nutr. 122(Suppl):832-837. https://doi.org/10.1093/jn/122.suppl_3.832.

Esposito, G., P. C. Irons, E. C. Webbb, and A. Chapwanya. 2014. Interactions between negative energy balance, metabolic diseases, uterine health and immune response in transition dairy cows. Anim. Reprod. Sci. 144:60-71. https://doi.org/10.1016/j .anireprosci.2013.11.007.

Fonseca, P. A. S., F. C. dos Santos, S. Lam, A. Suárez-Vega, F. Miglior, F. S. Schenkel, L. A. F. Diniz, S. Id-Lahoucine, M. R. S. Carvalho, and A. Cánovas. 2018. Genetic mechanisms underlying spermatic and testicular traits within and among cattle breeds: systematic review and prioritization of GWAS results. J. Anim. Sci. 96:4978-4999. https://doi.org/10.1093/jas/sky382.

Geishauser, T., D. Leslie, D. Kelton, and T. Duffield. 2001. Monitoring for subclinical ketosis in dairy herds. Compend. Contin. Educ. Pract. Vet. 23:65-71.

Geishauser, T., K. Leslie, T. Duffield, D. Sandals, and V. Edge. 1998. The association between selected metabolic parameters and left displaced abomasum in dairy cows. Zentralbl. Veterinärmed. A 45:499-511.

Gohary, K., M. W. Overton, M. Von Massow, S. J. LeBlanc, K. D. Lissemore, and T. F. Duffield. 2016. The cost of a case of subclinical ketosis in Canadian dairy herds. Can. Vet. J. 57:728-732.

Graber, M., S. Kohler, T. Kaufmann, M. G. Doherr, R. M. Bruckmaier, and H. A. van Dorland. 2010. A field study on characteristics and diversity of gene expression in the liver of dairy cows during the transition period. J. Dairy Sci. 93:5200-5215. https://doi.org/ 10.3168/jds.2010-3265.

Grum, D. E., J. K. Drackley, R. S. Younker, D. W. LaCount, and J. J. Veenhuizen. 1996. Nutrition during the dry period and hepatic lipid metabolism of periparturient dairy cows. J. Dairy Sci. 79:1850-1864.

Grummer, R. R. 1993. Etiology of lipid-related metabolic disorders in periparturient dairy cows. J. Dairy Sci. 76:3882-3896. https://doi .org/10.3168/jds.S0022-0302(93)77729-2.

Ha, N. T., C. Drögemüller, C. Reimer, F. Schmitz-Hsu, R. M. Bruckmaier, H. Simianer, and J. J. Gross. 2017. Liver transcriptome analysis reveals important factors involved in the metabolic adaptation of the transition cow. J. Dairy Sci. 100:9311-9323. https:// doi.org/10.3168/jds.2016-12454.

Ha, N.-T., J. J. Gross, A. van Dorland, J. Tetens, G. Thaller, M. Schlather, R. Bruckmaier, and H. Simianer. 2015. Gene-based mapping and pathway analysis of metabolic traits in dairy cows. PLoS One 10:e0122325. https://doi.org/10.1371/journal.pone .0122325 .

Hammon, H. M., G. Stürmer, F. Schneider, A. Tuchscherer, H. Blum, T. Engelhard, A. Genzel, R. Staufenbiel, and W. Kanitz. 2009. Performance and metabolic and endocrine changes with emphasis on glucose metabolism in high-yielding dairy cows with high and low fat content in liver after calving. J. Dairy Sci. 92:1554-1566. https://doi.org/10.3168/jds.2008-1634.

Hu, Z. L., C. A. Park, X.-L. Wu, and J. M. Reecy. 2013. Animal QTLdb: An improved database tool for livestock animal QTL/association data dissemination in the post-genome era. Nucleic Acids Res. 41:D871-D879. https://doi.org/10.1093/nar/gks1150.

Huang, H., J. Cao, Q. Hanif, Y. Wang, Y. Yu, S. Zhang, and Y. Zhang. 2019. Genome-wide association study identifies energy metabolism genes for resistance to ketosis in Chinese Holstein cattle. Anim. Genet. 50:376-380. https://doi.org/10.1111/age.12802.

Jones, J. M., J. C. Morrell, and S. J. Gould. 2000. Identification and characterization of HAOX1, HAOX2, and HAOX3, three human peroxisomal 2-hydroxy acid oxidases. J. Biol. Chem. 275:1259012597. https://doi.org/10.1074/jbc.275.17.12590.
Kadokawa, H., and B. G. Martin. 2006. A new perspective on management of reproduction in dairy cows: The need for detailed metabolic information, an improved selection index and extended lactation. J. Reprod. Dev. 52:161-168. https://doi.org/10.1262/jrd .17088 .

Kanehisa, M., S. Goto, Y. Sato, M. Furumichi, and M. Tanabe. 2012. KEGG for integration and interpretation of large-scale molecular data sets. Nucleic Acids Res. 40:D109-D114. https://doi.org/10 $.1093 /$ nar/gkr988.

Knapp, J. R. 1990. Lactation ketosis: Evaluation of current concepts. PhD Diss., Department of Animal Science, University of California, Davis.

Kroezen, V., F. S. Schenkel, F. Miglior, C. F. Baes, and E. J. Squires. 2018. Candidate gene association analyses for ketosis resistance in Holsteins. J. Dairy Sci. 101:5240-5249. https://doi.org/10.3168/ jds.2017-13374.

Lee, S., K. Cho, M. Park, T. Choi, S. Kim, and C. Do. 2016. Genetic parameters of milk $\beta$-hydroxybutyric acid and acetone and their genetic association with milk production traits of Holstein cattle. Asian-Australas. J. Anim. Sci. 29:1530. https://doi.org/10.5713/ ajas.16.0310.

Leek, B. F., and W. O. Reece. 2014. Digestão no Estômago do Ruminante. Pages 404-437 in Dukes, Fisiologia Dos Animais Domésticos, 12th ed. Guanabara Koogan.

Li, L. O., J. M. Ellis, H. A. Paich, S. Wang, N. Gong, G. Altshuller, R. J. Thresher, T. R. Koves, S. M. Watkins, D. M. Muoio, G. W. Cline, G. L. Shulman, and R. A. Coleman. 2009. Liver-specific loss of long chain acyl-CoA synthetase-1 decreases triacylglycerol synthesis and beta-oxidation and alters phospholipid fatty acid composition. J. Biol. Chem. 284:27816-27826. https://doi.org/10 .1074/jbc.M109.022467.

Li, P., X. B. Li, S. X. Fu, C. C. Wu, X. X. Wang, G. J. Yu, M. Long, Z. Wang, and G. W. Liu. 2012. Alterations of fatty acid $\beta$-oxidation capability in the liver of ketotic cows. J. Dairy Sci. 95:1759-1766. https://doi.org/10.3168/jds.2011-4580.

Loor, J. J., R. E. Everts, M. Bionaz, H. M. Dann, D. E. Morin, R. Oliveira, S. L. Rodriguez-Zas, J. K. Drackley, and H. A. Lewin. 2007. Nutrition-induced ketosis alters metabolic and signaling gene networks in liver of periparturient dairy cows. Physiol. Genomics 32:105-116. https://doi.org/10.1152/physiolgenomics.00188.2007.

McArt, J. A. A., D. V. Nydam, and G. R. Oetzel. 2012. Epidemiology of subclinical ketosis in early lactation dairy cattle. J. Dairy Sci. 95:5056-5066. https://doi.org/10.3168/jds.2012-5443.

McArt, J. A. A., D. V. Nydam, and M. W. Overton. 2015. Hyperketonemia in early lactation dairy cattle: A deterministic estimate of component and total cost per case. J. Dairy Sci. 98:2043-2054. https://doi.org/10.3168/jds.2014-8740.

McCabe, M., S. Waters, D. Morris, D. Kenny, D. Lynn, and C. Creevey. 2012. RNA-seq analysis of differential gene expression in liver from lactating dairy cows divergent in negative energy balance. BMC Genomics 13:193. https://doi.org/10.1186/1471-2164-13-193.

McCarthy, S. D., M. Waters, A. Kenny, G. Diskin, R. Fitzpatrick, J. Patton, D. C. Wathes, and D. G. Morris. 2010. Negative energy balance and hepatic gene expression patterns in high-yielding dairy cows during the early postpartum period: a global approach. Physiol. Genomics 42A:188-199. https://doi.org/10.1152/ physiolgenomics.00118.2010.

McGarry, J. D., and N. F. Brown. 1997. The mitochondrial carnitine palmitoyltransferase system. From concept to molecular analysis. Eur. J. Biochem. 244:1-14.

Mizutani, H., T. Sako, Y. Toyoda, T. Kawabata, N. Urumuhang, H. Koyama, and S. Motoyoshi. 1999. Preliminary studies on hepatic carnitine palmitoyltransferase in dairy cattle with or without fatty liver. Vet. Res. Commun. 23:475-480.

Nayeri, S., F. Schenkel, A. Fleming, V. Kroezen, M. Sargolzaei, C. Baes, A. Cánovas, J. Squires, and F. Miglior. 2019. Genome-wide association analysis for $\beta$-hydroxybutyrate concentration in milk in Holstein dairy cattle. BMC Genet. 20:58. https://doi.org/10.1186/ s12863-019-0761-9. 
Owen, O. E., S. C. Kalhan, and R. W. Hanson. 2002. The key role of anaplerosis and cataplerosis for citric acid cycle function. J. Biol. Chem. 277:30409-30412. https://doi.org/10.1074/jbc.R200006200.

Pryce, J. E., K. P. Gaddis, A. Koeck, C. Bastin, M. Abdelsayed, N. Gengler, F. Miglior, B. Heringstad, C. Egger-Danner, and K. Stock. 2016. Invited review: Opportunities for genetic improvement of metabolic diseases. J. Dairy Sci. 99:6855-6873. https://doi .org/10.3168/jds.2016-10854.

R Core Team. 2019. R: A language and environment for statistical computing. R Foundation for Statistical Computing, Vienna, Austria.

Renate, K., and H. Cernescu. 2009. Effects of negative energy balance on reproduction in dairy cows. Lucrări Stiintifice Medicină Veterinară, XLII(2).

Reynolds, C. K., P. C. Aikman, B. Lupoli, D. J. Humphries, and D. E. Beever. 2003. Splanchnic metabolism of dairy cows during the transition from late gestation through early lactation. J. Dairy Sci. 86:1201-1217. https://doi.org/10.3168/jds.S0022-0302(03)73704 -7 .

Rutherford, A. J., G. Oikonomou, and R. F. Smith. 2016. The effect of subclinical ketosis on activity at estrus and reproductive performance in dairy cattle. J. Dairy Sci. 99:4808-4815. https://doi.org/ $10.3168 /$ jds. $2015-10154$.

Sanders, K., J. Bennewitz, N. Reinsch, G. Thaller, E.-M. Prinzenberg, C. Kühn, and C. E. Kalm. 2006. Characterization of the DGAT1 mutations and the CSN1S1 promoter in the German Angeln dairy cattle population. J. Dairy Sci. 89:3164-3174. https://doi.org/10 .3168/jds.S0022-0302(06)72590-5.

Schäff, C., S. Börner, S. Hacke, U. Kautzsch, D. Albrecht, H. M. Hammon, M. Röntgen, and B. Kuhla. 2012. Increased anaplerosis, TCA cycling, and oxidative phosphorylationin the liver of dairy cows with intensive body fat mobilization during early lactation. J. Proteome Res. 11:5503-5514. https://doi.org/10.1021/pr300732n.

Seymour, D. J., A. Cánovas, C. F. Baes, T. C. S. Chud, V. R. Osborne, J. P. Cant, L. F. Brito, B. Gredler-Grandl, R. Finocchiaro, R. F. Veerkamp, Y. de Haas, and F. Miglior. 2019. Invited review: Determination of large-scale individual dry matter intake phenotypes in dairy cattle. J. Dairy Sci. 102:7655-7663. https://doi.org/ 10.3168/jds.2019-16454.

Song, L., H. Liu, Y. Wang, Y. Wang, J. Liu, Z. Zhou, H. Chu, P. Zhuang, and Y. Zhang. 2015. Application of GC/MS-based metabonomic profiling in studying the therapeutic effects of HuangbaiZhimu herb-pair (HZ) extract on streptozotocin-induced type 2 diabetes in mice. J. Chromatogr. B Analyt. Technol. Biomed. Life Sci. 997:96-104. https://doi.org/10.1016/j.jchromb.2015.05.003.

Sundrum, A. 2015. Metabolic disorders in the transition period indicate that the dairy cows' ability to adapt is overstressed. Animals (Basel) 5:978-1020. https://doi.org/10.3390/ani5040395.

Tetens, J., C. Heuer, I. Heyer, M. S. Klein, W. Gronwald, W. Junge, P. J. Oefner, G. Thaller, and N. Krattenmacher. 2015. Polymor- phisms within the APOBR gene are highly associated with milk levels of prognostic ketosis biomarkers in dairy cows. Physiol. Genomics 47:129-137. https://doi.org/10.1152/physiolgenomics .00126 .2014

van der Drift, S., K. Van Hulzen, T. Teweldemedhn, R. Jorritsma, M. Nielen, and H. Heuven. 2012. Genetic and nongenetic variation in plasma and milk $\beta$-hydroxybutyrate and milk acetone concentrations of early-lactation dairy cows. J. Dairy Sci. 95:6781-6787. https://doi.org/10.3168/jds.2012-5640.

Vordenbäumen, S., A. Braukmann, K. Petermann, A. Scharf, E. Bleck, A. von Mikecz, J. Jose, and M. Schneider. 2011. Casein a s1 is expressed by human monocytes and upregulates the production of GM-CSF via p38 MAPK. J. Immunol. 186:592-601. https://doi .org/10.4049/jimmunol.1001461.

Wang, Y., Y. Gao, C. Xia, H. Zhang, W. Qian, and Y. Cao. 2016. Pathway analysis of plasma different metabolites for dairy cow ketosis. Ital. J. Anim. Sci. 15:545-551. https://doi.org/10.1080/ 1828051X.2016.1180643.

Warde-Farley, D., S. L. Donaldson, O. Comes, K. Zuberi, R. Badrawi, P. Chao, M. Franz, C. Grouios, F. Kazi, C. T. Lopes, A. Maitland, S. Mostafavi, J. Montojo, Q. Shao, G. Wright, G. D. Bader, and Q. Morris. 2010. The GeneMANIA prediction server: Biological network integration for gene prioritization and predicting gene function. Nucleic Acids Res. 38:W214-W220. https://doi.org/10 $.1093 /$ nar/gkq537.

Weber, C., C. Hametner, A. Tuchscherer, B. Losand, E. Kanitz, W. Otten, H. Sauerwein, R. M. Bruckmaier, F. Becker, W. Kanitz, and H. M. Hammon. 2013. Hepatic gene expression involved in glucose and lipid metabolism in transition cows: Effects of fat mobilization during early lactation in relation to milk performance and metabolic changes. J. Dairy Sci. 96:5670-5681. https://doi .org $/ 10.3168 /$ jds.2012-6277.

$\mathrm{Xu}$, C., and Z. Wang. 2008. Comparative proteomic analysis of livers from ketotic cows. Vet. Res. Commun. 32:263-273. https://doi .org/10.1007/s11259-007-9028-4.

Zhu, Y., G. Liu, X. Du, Z. Shi, M. Jin, X. Sha, X. Li, Z. Wang, and X. Li. 2019. Expression patterns of hepatic genes involved in lipid metabolism in cows with subclinical or clinical ketosis. J. Dairy Sci. 102:1725-1735. https://doi.org/10.3168/jds.2018-14965.

\section{ORCIDS}

R. A. N. Soares ๑ https://orcid.org/0000-0002-4675-3978

M. M. M. Muniz @ https://orcid.org/0000-0003-0975-7926

M. A. M. Soares $\odot$ https://orcid.org/0000-0002-8268-3065

A. Cánovas @ https://orcid.org/0000-0002-0036-0757

F. Schenkel 1 https://orcid.org/0000-0001-8700-0633

E. J. Squires (® https://orcid.org/0000-0002-5288-5600 